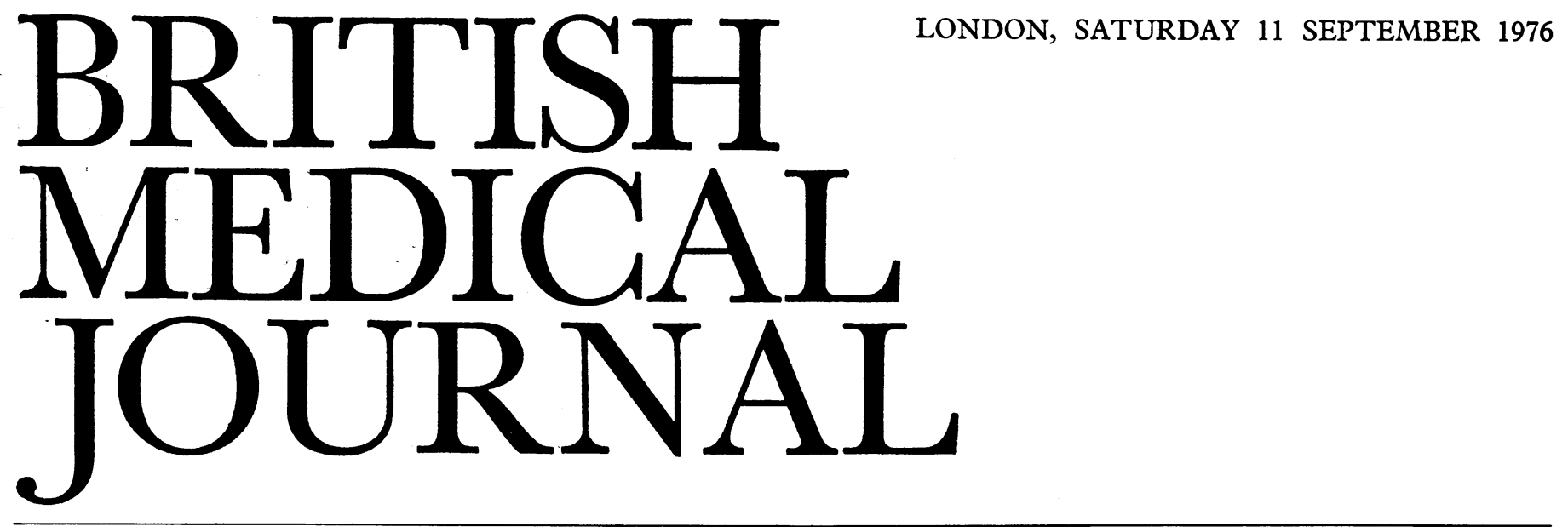

\title{
Disease at the Elephant
}

In common with so many contemporary institutions, the DHSS seems to have outgrown the concepts of its creators. Oversized, amorphous, and labyrinthine-like Mervyn Peake's Gormenghast-its ramifications have developed an almost neoplastic autonomy: free from any central control or direction, it continues to drain resources in a remorseless but seemingly purposeless growth.

More specifically, it has been said: "A sizable proportion of the work of the Department is self-inflicted. This need not be disadvantageous, if what is done is really necessary. But when the simple test [is applied] of asking whether particular activities are really necessary: whether the likely limitation of resources means that much of what is being worked on can ever be translated into reality: or whether there is any effective mechanism within the Department for saying 'no' to what may be desirable in an ideal world, or even interesting, or even beguiling, the answer is clearly that too much happens without any practical justification." That analysis formed the core of an inquiry into the working of the DHSS by a group of chairmen of regional health authorities and was published ${ }^{1}$ by the Department itself (though it is not, it seems, readily available to members of the public).

Showing a rare ability to find their way through bureaucratic fog, the chairmen set out in simple words their initial views on the way the DHSS ought to have been approaching the job of management. The top level should have four main functions: allocation of resources between capital and revenue and among regions; setting objectives for the Service; ensuring that health authorities were pursuing those objectives and providing a satisfactory quality of health care; and providing the few services which (by statute or for economic reasons) had to be a function of the DHSS itself. They also emphasised that at lower levels management should be organised so that it was absolutely clear which tier was responsible for which decision-and that any question referred upward should be settled with utmost dispatch; and that monitoring "did not mean meddling in the affairs of management teams at lower levels: nor should it involve the duplication of staff and effort which this involves."

How far real life at the Elephant differed from this blueprint became clear during the investigation. The complexity of the Department's working was, says the report, "almost totally baffling." In part this was due to two mistaken but well-intentioned beliefs. First was the concept that everyone with even a peripheral interest in a topic had to be given the chance to comment on it-so leading to a proliferation of paper and meetings and a state where the DHSS had to admit that it had no idea of the numbers or the purpose of the myriads of its internal working parties. The second reason was that successive Secretaries of State have put great emphasis on their statutory duty to answer in Parliament any question, however detailed, relating to the NHS. There are no fewer than 3000 parliamentary questions on the NHS each year and Dr Owen personally answers 1600 inquiries a month from MPs and members of the public. This attention to detail must have its effect throughout the Department and may go some way to explain the legendary delays health authorities experience in getting decisions and answers to their questions. Nevertheless, bogged down as it may be in all the detail, the DHSS should be able to distinguish between its executive and advisory functions: but the inquiry found that it could not. It also found widespread evidence of duplication of effort, and frustration and waste, especially in the lower tiers.

After detailed examination of the divisions and administrative groups at the DHSS, the inquiry team made some radical proposals for cuts in the size and range of the Department's functions. Staff concerned with health and personal social services should, it suggests, be separated from all the advisory responsibilities to other Government departments. Supporting services, such as supplies and research in hospital building, should be reorganised on an agency basis with management committees representing the DHSS and the NHS, with the user expected to pay for the services provided or requested. All detailed inquiries should be referred to the field authority concerned to answer direct to the inquirer. In consequence of these changes, it argues, the Department would be shrunk to a much smaller policy-making and executive body, with advisory functions clearly separated, uncluttered with any responsibilities not connected with the NHS.

Mr Ennals has (predictably) set up a "small joint steering committee" to examine these proposals, and has also created an NHS standing committee to advise ministers on general policy. The prospects for radical reform cannot, regrettably, be seen as bright. What the inquiry wants is for senior administrative staff to be freed of petty queries and day-to-day detail and so be given time to formulate policy, while the subsidiary tiers would be encouraged to stand on their own feet. Optimism that such a change might be possible ignores the sad reality that much of the malaise in the NHS (and elsewhere in Britain) is due to executives using the excuse of overwork to absolve them from the really difficult decisions they 
are paid to make. While the in-tray is piled high with work, who can challenge the alibi ? Sir Paul Chambers used to say he took only one or two decisions a year as chairman of ICI but he was paid to get them right. We can expect a simplified, streamlined NHS administration only if the top management is prepared to expose itself to the hazards of real decisionmaking and halt the drift into decay and despair.

${ }^{1}$ Regional Chairmen's Enquiry into the Working of the DHSS in Relation to Regional Health Authorities. London, DHSS, 1976.

\section{The closure of dirty and untidy wounds}

It takes courage to proclaim one's own mistakes, and P C Bewes $^{1}$ deserves our thanks for doing just that in his account in Tropical Doctor of the disasters that can result from primary closure of wounds, and for reiterating the lessons that were learned in 1915 and again and again in subsequent wars and campaigns. ${ }^{2-5}$ Among the surgeons in Britain today those best qualified to teach this subject are those in Belfast and in the Army, for they know only too well the consequences of illadvised primary suture and repair of destructive wounds so often heavily contaminated.

Healthy tissues with a good blood supply can defend themselves against bacterial invasion, but it is too little recognised that if a wound is closed, whether by suture or by skin grafts three to five days after proper surgical toilet, both the closure and the healing are as easily possible as on the day of wounding. Indeed, natural arrest of bleeding and subsidence of swelling may make both processes easier.

At a time when reattachment of severed parts is both fashionable and successful the necessarily drastic removal of dead and damaged tissue, especially muscle, from untidy wounds may go against the surgeon's inclination-unless he knows the penalties of too conservative an approach. The rules of basic surgical techniques are simple. Firstly, lay the wound widely open to allow drainage, to relieve compression, and to promote the circulation of blood and to expose for removal all dead and damaged tissues and foreign matter. Secondly, stop most of the bleeding; absolute haemostasis is not possible. Thirdly, loosely fill the wound with gauze and encase it in a firm, bulky, and absorbent dressing. Finally, support fractures comfortably. How many of today's surgeons have even heard of the Tobruk splint ${ }^{6}$ There are important special provisions. Open joints should be closed with the aid of synovial membrane or capsule; arteries should be covered by living fascia or muscle; and the brain should be covered by dura or a fascial patch. After three to five days the wound should be examined with general anaesthesia, and if it is healthy then it may be closed by suture or with split skin. If it is not healthy, at least it has been free to drain, and it may still be possible to remove tissue that has shown itself to be unhealthy and to achieve safe closure within a week or so of wounding.

Delayed primary closure is above all safe and it does not throw away any opportunities. For many years delayed primary repair of the injured hand has been advocated as the treatment of choice, ${ }^{78}$ and American experience in Vietnam has confirmed its safety and success, even with wounds of war. ${ }^{9}$ In the same way delayed primary fixation of fractures can be undertaken successfully, and there is good reason to suppose that rigid fixation may help to prevent infection. ${ }^{10}$
For those who shrink from putting nails or plates into such wounds there is external skeletal fixation.11 12

Why is there any problem ? The trouble is that in successive wars from 1917 onwards $^{2}$ it has been found that immediate closure of wounds and even elaborate repair may sometimes be carried out successfully, ${ }^{13}$ but the special conditions that justify this exception are often forgotten. For the vast majority of wounds, whether fresh, contaminated, or frankly septic and whether tidy, untidy, or massively destructive, there is but one simple principle, and that is to bring living, healthy tissues together and keep them together until they grow together. When there is doubt about viability it is a useful rule that any part of great functional or structural importance should in the first instance be preserved if it has a chance of survival but that tissues of small importance should be sacrificed if there is any chance that they will not survive. The application of this rule to bone requires judgment. Having carried out exploration and toilet-decompression and the removal of dead tissue and foreign matter-no surgeon is obliged to do more than dress and support the part comfortably. Only in special circumstances should a few suitably experienced surgeons attempt to do more than that.

Of the role of antibacterial agents it is simplest to say that they may usefully supplement good surgical treatment but that they can never replace it.

${ }^{1}$ Bewes, P C, Tropical Doctor, 1976, 6, 108.

2 Macpherson, W G, et al, eds, History of the Great War. Medical Services. Surgery of the War Vol II. London, HMSO, 1922.

3 Edwards, H C, Lancet, 1945, 1, 583.

4 Watts, J C, Annals of the Royal College of Surgeons of England, 1960, 27, 125.

5 Boyd, N A, Annals of the Royal College of Surgeons of England, 1975, 56, 15.

${ }^{6}$ British Fournal of Surgery, War Surgery Supplement No 2, 1947, p 289.

7 Iselin, M, Fournal of the International College of Surgeons, 1961, 36, 374.

${ }^{8}$ Madsen, E, Fournal of Bone and Foint Surgery, 1964, 46B, 357.

9 Jabaley, M E, and Peterson, H D, Annals of Surgery, 1973, 177, 167.

10 McNeur, J C, Fournal of Bone and foint Surgery, 1970, 52B, 54.

11 Chacha, P B, Injury, 1974, 6, 154.

${ }^{12}$ Ronen, G M, Michaelson, M, and Waisbrod, H, Injury, 1974, 6, 94.

13 Naggan, L, Iniury, 1976, 7, 279.

\section{The earch for as psychiatric Esperanto}

An international congress on transcultural psychiatry-the first held in Britain for ten years-was organised recently by the World Federation for Mental Health and the University of Bradford, an appropriate venue with its large wellestablished Asian community. The sheer numbers of immigrants in most parts of the world have presented psychiatrists with so many urgent psychological and social problems that they have had little time to become absorbed in the collection and analysis of exotica, so much of the congress dealt with everyday aspects of mental illness.

A necessary preliminary to tackling psychiatric problems in immigrants is a "culture-free" instrument for rating psychiatric symptoms. The psychiatrist has no pathological investigations to back up his diagnosis, which rests entirely on eliciting signs and symptoms and on the history. Standardised clinical instruments do exist, one of the most widely used being the "present state examination," a semistructured interview which closely resembles the psychiatric clinical examination except that there is a core of stipulated questions and a glossary 